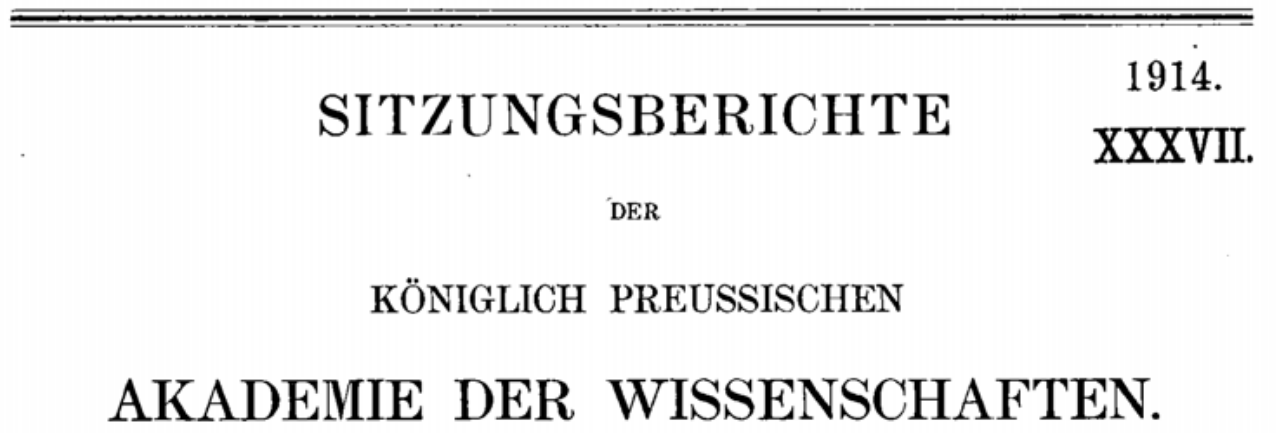

Sitzung der philosophisch-historischen Classe vom 29. October.

\title{
Die Palimpsestphotographie.
}

Ein Beitrag zu den philologisch-historischen Hilfswissenschaften.

Von P. R. Kögel, O.S. B.

in Wessobrunn, Bayern.

Sonderabdruck.

Verlag der Königlichen Akademie der Wissenschaften.

In Commission bei Georg Reimer.

(Preis « 0.50) 